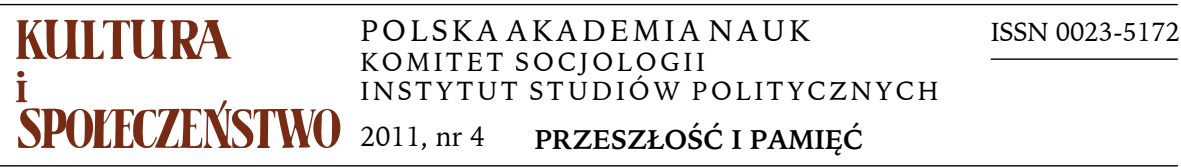

KATARZYNA JAGODZIŃSKA

Międzynarodowe Centrum Kultury w Krakowie

Uniwersytet Jagiellonski

\title{
HISTORYCZNE MURY DLA NOWYCH MUZEÓW MUZEALNA MODA NA POCZĄTKU XXI WIEKU
}

W 2010 r. Zagłębie Ruhry świętowało zwieńczenie procesu transformacji polegającego na przełamywaniu za sprawą kultury dotychczasowego wizerunku regionu opartego na przemyśle ciężkim. Nadanie Essen tytułu Europejskiej Stolicy Kultury stało się impulsem do rewitalizacji kopalń, fabryk i zakładów produkcyjnych, w których powstały muzea, hale wystawowe i koncertowe, uczelnie. Na zdegradowanych wcześniej terenach wyrosły również nowe obiekty budujące dialog starego z nowym. W ostatniej dekadzie XX wieku w londyńskiej dzielnicy Southwark trwały prace budowlane w starej miejskiej elektrowni, która $\mathrm{w}$ roku milenijnym rozpoczęła swoje drugie życie jako Tate Modern. W latach osiemdziesiątych w Liverpoolu została przeprowadzona rewitalizacja portu - wizytówką Albert Dock zostało zlokalizowane w historycznym magazynie portowym tzw. Tate Północy, czyli otwarte w 1988 r. Tate Liverpool - pierwszy oddział londyńskiego muzeum. Museo Reina Sofia w Madrycie, MACRO Testaccio w Rzymie, Hamburger Bahnhof - Museum für Gegenwart w Berlinie, Musée d'Orsay w Paryżu... długo można wyliczać. Arcydzieła sztuki nowożytnej w pałacach i zamkach bądź zabytki techniki w byłych zakładach przemysłowych to połączenia jak najbardziej naturalne. Dysonans powstaje, gdy eksponaty trafiające do zaadaptowanego na muzeum budynku nie mają związku z jego przeszłością. Taka tendencja co najmniej od lat osiemdziesiątych XX wieku święci triumfy w światowym muzealnictwie.

Modę na adaptowanie istniejących budynków na potrzeby muzeów, a także centrów sztuki, kultury, bibliotek, sal koncertowych, wyznaczyły Stany Zjednoczone, Wielka Brytania, Francja, Włochy i Niemcy. Instytucje otwarte $\mathrm{w}$ tych krajach $\mathrm{w}$ budynkach pochodzących $\mathrm{z}$ architektonicznego recyclingu

Adres do korespondencji: k.jagodzinska@mck.krakow.pl 
stały się źródłem inspiracji dla wielu obiektów powstających na terenie całej Europy (i nie tylko). Od lat pięćdziesiątych XX wieku karierę robi pojęcie industrialnej archeologii, a „recycling budynków - jak pisze Neil Cossons (2008, s. 253-255) - stał się w ciągu ostatnich trzydziestu lat nadzwyczajnym zjawiskiem. [...] Większość średniowiecznych kościołów wciąż służy jako miejsca kultu, większość średniowiecznych opactw i klasztorów, które przetrwały, jest zachowana, z reguły przez państwo, jako ruiny dla celów archeologicznych i społecznego zrozumienia. Większość budynków mieszkalnych, z jakiegokolwiek okresu, wciąż jest zamieszkiwana. Jednak większość zakładów i fabryk [...] albo przestała istnieć, albo została skolonizowana dla nowych funkcji, zupełnie odmiennych od tych, dla których powstały. [...] Odgrywają teraz nową rolę gospodarczą i społeczną. Są to jedynie skorupy, lupiny [...] Będą jednak stanowić najbardziej widoczne przypomnienie - prawdopodobnie jedyne czytelne - przemysłu w krajobrazie". Adaptowanie budynków postindustrialnych do pełnienia innych funkcji, w tym funkcji kulturalnych, stało się tematem niezliczonych publikacji - albumów, katalogów, ale też tekstów teoretycznych. Spośród nich trzeba wymienić przede wszystkim: New Uses for Old Buildings (1975) i Re-architecture: Old Buildings / New Uses (1989) autorstwa Sherbana Cantacuzino oraz Industrial Buildings: Conservation and Regeneration pod redakcją Michaela Strattona (2000).

W Polsce wykorzystanie istniejących budynków na potrzeby muzealne nie jest zjawiskiem nowym - wielokrotnie miejskie pałace, kamienice, zamki i różnego typu gmachy o charakterze rezydencjonalnym lub reprezentacyjnym były przekształcane $\mathrm{w}$ muzea. Zazwyczaj jednak charakter zbiorów był związany z wcześniejszą funkcją budynku. Wystarczy wymienić cały szereg miejskich muzeów historycznych. Także sztuka współczesna znajdywała swoje miejsce w takich siedzibach. Przykładem, od którego zaczęła się historia muzeów sztuki współczesnej w Polsce, jest neorenesansowy Pałac Poznańskich w Łodzi, w którym od 1946 r. działa Muzeum Sztuki ${ }^{1}$. W 1984 r. działalność w budynku zabytkowego hotelu rozpoczęło Muzeum Śląskie w Katowicach. W 1985 r. Zamek Ujazdowski w Warszawie został przekazany na potrzeby Centrum Sztuki Współczesnej. Jest to jednak przypadek szczególny, gdyż nie jest to oryginalny barokowy gmach, którego budowa rozpoczęła się w 1606 r., lecz jego rekonstrukcja pochodząca $z$ lat siedemdziesiątych XX wieku. Wraz ze zmianą systemu politycznego w Polsce pojawiły się trendy od lat występujące w krajach zachodnich - w przypadku muzeów było to zwłaszcza adaptowa-

\footnotetext{
${ }^{1}$ Ekspozycja w Pałacu Poznańskich została otwarta w 1948 r. W 1931 r. Władysław Strzemiński oficjalnie przekazał Wydziałowi Oświaty i Kultury Magistratu miasta Łodzi kolekcję międzynarodowej sztuki nowoczesnej, na którą złożyły się dary polskich i zagranicznych artystów. Pierwszym miejscem prezentacji zbiorów były dwie sale otwartego w 1930 r. w łódzkim ratuszu Miejskiego Muzeum Historii i Sztuki im. Juliana i Kazimierza Bartoszewiczów.
} 
nie budynków o charakterze poprzemysłowym (przede wszystkim na muzea i centra sztuki, ale także na muzea historyczne).

Zamierzam tu przedstawić polskie inwestycje muzealne zrealizowane na terenie historycznych budynków o różnej proweniencji, w przypadku których funkcja nadana nie jest wypadkową pierwotnej funkcji gmachu. W latach 2004-2010 zostały otwarte cztery takie muzea - dwa historyczne i dwa artystyczne, a kilka kolejnych znajduje się na etapie projektowym oraz w sferze planów. Takie ujęcie tematu pozwala poddać pod rozwagę co najmniej trzy problemy: kwestię zespolenia zastanej architektury z funkcjami muzealnymi, zagadnienia odwołań do historycznej tożsamości obiektu oraz relacji, jakie instytucja zamknięta $\mathrm{w}$ historycznych murach buduje $\mathrm{z}$ otoczeniem. Jak zaznaczyłam, muzea w zabytkowych budynkach wykorzystywanych w przeszłości w przemyśle, ciężkim bądź lekkim, to tendencja mocno zaznaczająca się $\mathrm{w}$ światowym muzealnictwie. Polskie instytucje podążające za sprawdzonymi rozwiązaniami w nią się wpisują. Na gruncie analizy porównawczej współczesnych polskich muzeów warto więc zadać pytanie: Czy muzea są skazane na podążanie za modą? Innymi słowy: czy muzea muszą być modne?

\section{PUNKT WYJŚCIA DLA NOWYCH MUZEÓW}

Momentem zwrotnym dla polskich muzeów, a także infrastruktury sztuki współczesnej, był rok 2004, który — jako data przystąpienia Polski do struktur Unii Europejskiej — okazał się symboliczny nie tylko w wymiarze politycznym i społecznym, ale także na gruncie kultury współczesnej. W momencie zmiany ustroju zapóźnienie Polski w zakresie infrastruktury kulturalnej było ogromne i w ostatnim dziesięcioleciu XX wieku nie istniała wola polityczna zmiany tej sytuacji. Dorota Folga-Januszewska w przekrojowym artykule poświęconym polskim muzeom w latach 1989-2009 daje ekspertyzę ich zmieniającej się kondycji, dla której niezwykle istotna była połowa lat dziewięćdziesiątych (Folga-Januszewska 2009, s. 19). Z uwagi na brak zestandaryzowanych sposobów prowadzenia badań w zakresie muzealnictwa, a także jednoznacznej kwalifikacji instytucji jako muzeum, istnieją duże rozbieżności co do liczby muzeów w Polsce. Folga-Januszewska w swojej ekspertyzie przyjęła liczbę 916 muzeów działających w Polsce w roku $2007^{2}$. To oczywiście liczba uwzględniająca wszystkie typy muzeów, różniących się zarówno charakterem zbiorów, jak i statusem organizacyjnym. Po 1989 r. liczba muzeów systematycznie zwiększała się, jednak nie oznaczało to powstawania nowych instytucji, lecz jedynie zmiany w praktyce prowadzenia muzealnych statystyk i wyodrębnienie muzeów jako osobnych podmiotów $z$ większych struktur organizacyjnych, co nastąpiło po nowelizacji ustawy o muzeach w 2007 r. W polskich muzeach trwał wów-

\footnotetext{
2 Taka liczba znalazła się w bazie danych PKN ICOM i Krajowego Ośrodka Badań i Dokumentacji Zabytków. Za ten sam okres GUS podał liczbę 720 muzeów (Folga-Januszewska 2009, s. 19).
} 
czas impas, a nawet kryzys, związany przede wszystkim z niedostatecznym finansowaniem i kwestiami formalnoprawnymi. Na skutek likwidacji funduszy przeznaczonych na zakupy prac muzealne kolekcje w pierwszej połowie lat dziewięćdziesiątych prawie przestały się powiększać.

Zmiany nastąpiły dopiero w połowie dekady. Folga-Januszewska (2009, s. 26-27) wskazuje na intensyfikację badań naukowych, wystaw, szkoleń, konferencji, poprawę poziomu opieki nad zbiorami, wdrożenie standardów klimatycznych i konserwatorskich, odbudowę dawnych i nawiązywanie nowych relacji międzynarodowych. W 2004 r. Ministerstwo Kultury zainaugurowało program „Znaki Czasu”, którego celem miało być stworzenie sieci kolekcji sztuki współczesnej w regionach, rozbudzenie publicznego mecenatu nad współczesną twórczością, jej promocja $\mathrm{w}$ społeczeństwie, a także - $\mathrm{w}$ dalszej perspektywie - zainicjowanie przez powstałe $\mathrm{w}$ ramach programu stowarzyszenia i fundacje tworzenia tzw. centrów nowoczesności, czyli miejsc stałej prezentacji kolekcji, których rolą miałaby być aktywna działalność edukacyjna i promocyjna na rzecz sztuki ${ }^{3}$. Po zmianie ustroju nie tylko nie rozrastały się kolekcje, również prawie $\mathrm{w}$ ogóle nie powstawały nowe budynki muzealne. $\mathrm{Z}$ dużych inwestycji w 1989 r. został ukończony Gmach Główny Muzeum Narodowego w Krakowie (budowa rozpoczęta w 1934 r.), w 2001 r. ukończono nowe skrzydło Muzeum Narodowego w Poznaniu (wznoszone od 1977 r.!), a w latach 1993-1994 powstało w Krakowie Centrum Sztuki i Techniki Japońskiej Manggha (od 2007 r. muzeum).

\section{HISTORIA W ZABYTKOWYCH MURACH}

Instytucjonalny impas przełamało Muzeum Powstania Warszawskiego pierwsze prawdziwie nowoczesne, wielkie polskie muzeum, zarówno z uwagi na sposób prowadzenia narracji wystawy, jak i marketingową orientację. Muzeum, które już w pierwszym roku funkcjonowania odniosło frekwencyjny sukces, jest efektem polityki historycznej ówczesnego prezydenta Warszawy. Chęć zbicia kapitału politycznego wyzwoliła lawinę muzealnych projektów w całej Polsce. Historia muzeum rozpoczęła się w 1981 r., jeszcze przed wprowa-

${ }^{3} \mathrm{~W}$ sumie powstało szesnaście regionalnych organizacji. Zgodnie $\mathrm{z}$ założeniem $\mathrm{w}$ każdym województwie miała powstać jedna, ale w województwie mazowieckim nie było takiej potrzeby (istniało wiele kolekcji w Warszawie oraz Muzeum Sztuki Współczesnej — oddział Muzeum Okręgowego w Radomiu), w podkarpackim nie znaleźli się chętni, a w śląskim powstały dwie kolekcje w Katowicach i Częstochowie. Zakupy do kolekcji były finansowane $z$ budżetu przez bardzo krótki okres. W 2007 r. narodowy program kultury został przekształcony w program operacyjny „Znaki Czasu", w którym o środki mogły starać się wszystkie instytucje sztuki w kraju (wcześniej były to środki zarezerwowane dla organizacji powstałych w ramach „Znaków Czasu”). Z końcem 2008 r. program został zlikwidowany. To podstawowa różnica między polskim programem a programem Fonds régionaux d'art contemporain wdrożonym we Francji w latach osiemdziesiątych XX wieku, który stanowił inspirację dla polskiego ministerstwa. Tamtejszy program ma zapewnione coroczne finansowanie $z$ budżetu. 
dzeniem stanu wojennego, kiedy to zapadła decyzja o umiejscowieniu go na terenie Banku Polskiego w Warszawie — ostatniej zachowanej reduty powstańczej. Muzeum zostało zarejestrowane w 1983 r. i działało na terenie Muzeum Historycznego miasta stołecznego Warszawy. Dwa lata później rozstrzygnięto konkurs architektoniczny na koncepcję muzeum, w którym zwyciężył projekt Konrada Kuczy-Kuczyńskiego i Andrzeja Miklaszewskiego, jednak na skutek problemów formalnych nie został zrealizowany (pierwotnie muzeum miało zajmować $3500 \mathrm{~m}^{2}$, powierzchnia ta była stopniowo ograniczana do $2500 \mathrm{~m}^{2}$ ). W latach 2002-2003 pojawił się plan zlokalizowania go w podziemiach zabytkowego zbiornika gazu na warszawskiej Woli. Tematycznie muzeum zostałoby powiązane $z$ planowaną wówczas przez Andrzeja Wajdę w tej właśnie lokalizacji panoramą Powstania Warszawskiego. Do jej realizacji ostatecznie nie doszło. 2 lipca 2003 r. prezydent Warszawy, Lech Kaczyński, ogłosił decyzję o utworzeniu Muzeum Powstania Warszawskiego na terenie dawnej elektrowni tramwajowej przy ulicy Przyokopowej, a jego otwarcie zapowiedział na rok następny, w przededniu sześćdziesiątej rocznicy wybuchu powstania. Była to realizacja obietnicy wyborczej złożonej w roku poprzednim i zarazem sposób na zbicie kapitału, który okazał się przydatny w wyborach prezydenckich w 2005 r.

Muzeum miało powstać w rekordowym tempie. Konkurs architektoniczny został rozpisany w sierpniu, rozstrzygnięto go z końcem października, prace budowlane rozpoczęły się w kwietniu 2004 r., już 31 lipca świętowano otwarcie muzeum (jedynie część gmachu i niewielka część ekspozycji były wtedy gotowe), stała ekspozycja została otwarta miesiąc później. Gmach wybrany na siedzibę muzeum - w przeciwieństwie do pierwotnie planowanego - nie ma większego związku z Powstaniem Warszawskim. Pisze o tym Maria Wiśniewska, która walczyła w powstaniu: „Uzasadnienie historyczne słabsze niż w przypadku Banku Polskiego - reduty Starego Miasta broniącej się aż do jego upadku. Po tej stronie ulicy Towarowej już od pierwszych dni sierpnia panowali Niemcy, ale po drugiej stronie, wówczas dużo węższej jezdni, rozciągał się tzw. Twardy Front, tereny od 1 sierpnia aż do 2 października bronione przez żołnierzy zgrupowania "Chrobry II»" (Wiśniewska 2004, s. 28). Elektrownia tramwajowa powstała w latach 1905-1908. Jest to obiekt w stylu neoromańskim z elewacjami ceglano-tynkowanymi. Andrzej Kiciński pisząc na łamach „Muzealnictwa” o konkursie architektonicznym, na który napłynęło (zaledwie!) czternaście prac, stwierdził, że w budynku nie ma „nic, co mogłoby się kojarzyć emocjonalnie, plastycznie i historycznie z Powstaniem. Moc zdefiniowanej, obojętnej dla Powstania, architektury musiała odstraszać" (Kiciński 2004, s. 40). Zwyciężył projekt krakowskiego Studia Architektonicznego pod kierunkiem Wojciecha Obtułowicza. Warunki konkursu nie pozwalały na stworzenie architektonicznej ikony, ograniczyły bowiem projekt do istniejących zabudowań. Silnym nowym akcentem kompleksu jest jedynie wieża widokowa stanowiąca substytut dominującego w przeszłości nad założeniem ko- 
mina (opis architektury zob. Kiciński 2004, s. 40). Projekt obejmował również przestrzeń wokół hal wystawowych - aranżację parku oraz wzniesienie tzw. Muru Pamięci z wyrytymi nazwiskami poległych powstańców.

Pod względem funkcjonalnym i formalnym nasuwają się uzasadnione skojarzenia $z$ Tate Modern, które powstało w obrębie murów nieczynnej londyńskiej elektrowni - młodszej od tej w Warszawie, zbudowanej w latach 1947-1969. W obu przypadkach elewacje zewnętrzne pozostały nienaruszone, a „wnętrzności" zostały usunięte, powstały nowe kondygnacje i trakty komunikacyjne. Współczesnym akcentem muzeum w Londynie jest szklany prostopadłościan — „akwarium” - nałożony na ceglany korpus, a w Warszawie stała się nim wysoka na $32 \mathrm{~m}$ wieża. Powierzchnię ponad $3000 \mathrm{~m}^{2}$ stopniowo wypełniła stała ekspozycja zaprojektowana przez Mirosława Nizio, Jarosława Kłaputa i Dariusza Kunowskiego. O sukcesie przedsięwzięcia zdecydował przede wszystkim inny, nowatorski na polskim gruncie sposób mówienia o historii. Narracja opiera się na scenograficznym rozmachu, którego częścią są eksponaty, repliki materiałów ulotnych i zdjęć, muzyka, filmy, światło oraz odtworzone elementy wyposażenia wnętrz, kina, ulic, kanałów. Użyte środki mają na celu wywołanie atmosfery 63 powstańczych dni.

Muzeum stało się manifestacją patriotyzmu, ale też pomnikiem współczesnej władzy politycznej budującej swój wizerunek na kanwie pojęć takich jak pamięć, przeszłość i tożsamość. Za sukcesem muzeum stoi Jan Ołdakowski, dyrektor muzeum oraz do 2010 r. członek Prawa i Sprawiedliwości, który tworzył muzeum wraz z kilkoma innymi członkami partii. Jeden $z$ nich, Paweł Kowal (2010, s. 9), w oficjalnym przewodniku po muzeum pisze, że „elektrownia stała się swego rodzaju patriotyczną świątynią”. Zdecydowanie stała się świątynią marketingowego sukcesu mówiącego o jednym z największych polskich zrywów wolnościowych. Do muzeum ściągają tłumy - to obowiązkowy punkt zwiedzania stolicy i obowiązkowa lekcja historii dla szkół wszystkich szczebli. W 2010 r. liczba odwiedzin przekroczyła dwa i pół miliona. Muzeum zwyciężyło w rozpisanym w 2007 r. przez „Gazetę Wyborczą” internetowym konkursie na nową ikonę Warszawy. Było promowane jako: „Najnowocześniejsze muzeum w kraju. Zapomnijcie o rzędach gablot z nudnymi eksponatami. Tu historia pokazana jest po ludzku, tłumy młodych wychodzą z wypiekami na twarzy" ([wot] 2007). Współczesny język mówienia o przeszłości rzeczywiście sprawdził się (instytucja określa się mianem muzeum wnuków i dziadków). Oprócz multimediów w programie muzeum znalazły się koncerty muzyki popularnej, spektakle, a wewnętrzna strona muzealnego kompleksu, tuż za tzw. Murem Pamięci, to tzw. Mur Sztuki dekorowany muralami autorstwa znanych współczesnych artystów odnoszących się do historii miejsca ${ }^{4}$, jednak rekonstrukcjom i inscenizacjom, jakie mają miejsce na terenie muzeum,

${ }^{4}$ Murale namalowali m.in. Edward Dwurnik, Wilhelm Sasnal, Bartek Materka, Stasys Eidrigevicius, grupa Twożywo. 
coraz częściej zarzuca się - wcale nie bezpodstawnie - banalizację i cepeliadę 5 .

Muzeum Powstania Warszawskiego - niezależnie od oceny uwikłania politycznego, koncepcji programowej, orientacji marketingowej czy lokalizacji jest pierwszym wielkim nowoczesnym muzeum w Polsce, pierwszym, które wykorzystało obiekt postindustrialny w sposób nie związany z jego wcześniejszą funkcją oraz stało się punktem odniesienia dla kolejnych instytucji tego rodzaju. To właśnie ze stołecznym muzeum porównuje się Fabrykę Schindlera — oddział Muzeum Historycznego Miasta Krakowa (MHK). Okoliczności powstania krakowskiego muzeum są zupełnie inne niż warszawskiego - w stolicy celem było upamiętnienie powstania, w Krakowie pierwszorzędne znaczenie miała lokalizacja. Miejsce, nagłośnione przez nagrodzony siedmioma Oskarami film Stevena Spielberga Lista Schindlera, należało przekształcić w muzeum, nie było jednak zgody co do jego charakteru. W dywagacjach pojawiały się pomysły na Centrum im. Schindlera, Muzeum Miejsca, Muzeum Pamięci, Muzeum „Żegoty”, Muzeum Sprawiedliwych Wśród Narodów Świata (pozyskano nawet zgodę Instytutu Yad Vashem na użycie nazwy). Orędownikiem utworzenia muzeum poświęconego Żydom i Oskarowi Schindlerowi był Aleksander Skotnicki, autor książek i wystaw poświęconych Schindlerowi i uratowanym przez niego Żydom: „chciałem skupić się na genius loci tego miejsca - wyjaśniał. - Lista Schindlera to nie masa ludzi, ale konkretne osoby $z$ imienia i nazwiska. Dla potomków ludzi tam uratowanych niezwykle istotna jest możliwość odnalezienia swoich dziadków czy pradziadków. Jest więc zapotrzebowanie, aby pokazywać konkretnych ludzi i konkretne fakty" (zob. Jagodzińska 2009, s. 19). Ostatecznie zapadła decyzja o nietworzeniu nowej instytucji, lecz o włączeniu jej w strukturę MHK, które zobowiązało się opracować wystawę stałą. W 2010 r. na terenie budynku administracyjnego dawnej Niemieckiej Fabryki Naczyń Emaliowanych Oskara Schindlera została otwarta wystawa stała Kraków

\footnotetext{
5 Trafnie ujął to Adam Szostkiewicz, pisząc na łamach „Polityki”: „ta cepelia to jeden z efektów wpuszczenia historii $\mathrm{w}$ młyn kultury masowej. To, co $z$ tego młyna wypada, może być cepelią z górnej półki, ale wciąż cepelią — produktem do masowej konsumpcji, po którym raczej nie oczekujemy pogłębienia tematu, zwłaszcza takiego jak patriotyzm czy sens powstania. Masowość przekazu niemal zawsze oznacza uproszczenie i spłycenie. Nie ma nieszczęścia, jeśli sedno sprawy jest zachowane: powstańcze inscenizacje są po to, by pokazać, jak to mogło wyglądać, ale bez wchodzenia w buty powstańców. [...] Telewizyjne «Wiadomości» 1 sierpnia nadano z Muzeum Powstania Warszawskiego. Powstanie było jedynym tematem przez 20 minut głównego programu informacyjnego o największej widowni w Polsce. Więcej wiadomości z kraju i świata można było usłyszeć w dzienniku TV Trwam. "Wiadomości» skupiły się na powstańcach i zasługach Lecha Kaczyńskiego jako ojca założyciela Muzeum. O udziale w powstańczych uroczystościach prezydenta-elekta (skądinąd spowinowaconego $z$ dowódcą powstania gen. Borem-Komorowskim) ani słowa. Po takim serwisie poszedł w eter ostry utwór rockowy ku chwale poległych, a kiedy wybrzmiał, blok reklamowy rozpoczęła pochwała jogurtu polepszającego pracę jelit. Tak się wypacza i banalizuje wielki temat naszej historii. Polityka historyczna nie przemoże kultury masowej. Ostatecznie z historii zostają strzępy, a z polityki - propaganda" (Szostkiewicz 2010, s. 25).
} 
- czas okupacji 1939-1945. Uzasadnieniem dla wyboru tematu była konieczność przedstawienia losów Schindlera „W szerokim kontekście wydarzeń i zjawisk zachodzących w ówczesnym Krakowie. - Jak bowiem wyjaśniała Monika Bednarek, kierownik oddziału Fabryka Schindlera — pokazanie tych postaci w kontekście będzie dla widzów ciekawsze, bardziej wzbogacające, a przy tym bliższe prawdy historycznej, gdyż wydarzenia rozgrywające się na Lipowej nie działy się w oderwaniu od ogólnej polityki nazistów i wydarzeń w mieście" (zob. Jagodzińska 2009, s. 19).

Wystawa została zaaranżowana $\mathrm{w}$ wyremontowanym, trzykondygnacyjnym budynku przy ulicy Lipowej, zajmuje powierzchnię $2000 \mathrm{~m}^{2}$. Związek $\mathrm{z}$ historią miejsca został zachowany, jednak stanowi on tylko część muzealnej narracji. W 1937 r. na krakowskim Zabłociu rozpoczęła działalność Pierwsza Małopolska Fabryka Naczyń Emaliowanych i Wyrobów Blaszanych „Rekord” Izraela Kohna, Wolfa Luzera Glajtmana i Michała Gutmana, a od listopada 1939 do 1944 r. Niemiecka Fabryka Naczyń Emaliowanych Oskara Schindlera. Zabudowania fabryki pochodzą z lat 1940-1943. Najpierw powstał budynek mieszczący biuro płac i gabinety lekarskie, a także stołówka, stajnie i garaże, a następnie hala fabryczna, magazyny i trzypiętrowy budynek biurowy, w którym znajdowały się między innymi pokoje mieszkalne Schindlera. Fabryka produkowała przede wszystkim garnki kuchenne, patelnie, wiadra i menażki dla Wehrmachtu. Od 1941 r. stała się również zakładem zbrojeniowym. Początkowo zatrudniani byli głównie Polacy, później coraz liczniej pracujący za darmo Żydzi ${ }^{6}$. Po wojnie fabryka została znacjonalizowana, w latach 1948-2002 na jej terenie działał zakład produkujący podzespoły telekomunikacyjne. Częścią muzealnej ekspozycji jest odtworzony $\mathrm{w}$ autentycznym miejscu gabinet Schindlera z przylegającym do niego sekretariatem ${ }^{7}$. W jego przestrzeni znalazła się również współczesna instalacja nawiązująca do pierwotnej funkcji fabryki - jest nią swojego rodzaju „pomnik" z metalowych naczyń (prefabrykatów produkowanych w fabryce naczyń emaliowanych), w którego wnętrzu znalazła się rotunda z wyrytymi nazwiskami wszystkich osób ocalonych przez Schindlera.

Krakowska wystawa korzysta z podobnej gamy środków co Muzeum Powstania Warszawskiego, czyli artefaktów i ich replik ujętych w ramy potraktowanej z rozmachem scenografii (autorami aranżacji plastycznej są Michał Urban i Łukasz Czuj). Michał Niezabitowski, dyrektor MHK, stwierdził, że

6 Od maja 1943 do sierpnia 1944 r. przy fabryce funkcjonował podobóz obozu pracy przymusowej w Płaszowie. W związku z jego likwidacją Schindler otrzymał zezwolenie na wywiezienie tysiąca żydowskich robotników do swojej nowej fabryki zbrojeniowej w Brünnlitz, będącej podobozem obozu koncentracyjnego Gross-Rosen.

7 Oryginalne wyposażenie nie zachowało się. Pierwotnie planowano je zrekonstruować, ale okazało się, że muzeum nie dysponuje wiarygodnymi opisami pomieszczeń. Dlatego w gabinecie Schindlera stanęło biurko $z$ epoki, które sygnalizuje jego pierwotną funkcję oraz znalazła się instalacja, natomiast w sekretariacie opowiedziana została biografia właściciela fabryki (Bednarek 2010, s. 49). 
„wystawę muzealną dzisiaj nie tyle zwiedza się, aby pozyskać określoną wiedzę, co się w niej uczestniczy, by jej doświadczyć, doznać, przeżyć" (Niezabitowski 2010, s. 16). Ponadto, jak to ujął Andrzej Chwalba (2010, s. 12), „placówka pełni funkcję centrum pamięci o czasach Zagłady". Nie odżegnuje się przy tym od komercyjnego sukcesu filmu, który przysporzył miejscu popularności - fotosy z planu filmowego wypełniają ściany muzealnej kawiarni. To właśnie ten filmowy sukces miejsca, jego swoista sakralizacja, stanął u podstaw pomysłu przeznaczenia fabryki na cele muzealne (konkretnie dwóch odmiennych muzeów). W 2005 r. w wywiadzie prasowym prezydent Krakowa, Jacek Majchrowski, przyznał: ,jest to miejsce, gdzie w promocję i reklamę zainwestowano już kilka milionów dolarów. [...] Nadal, każdego dnia, przyjeżdżają pod fabrykę autokary z wycieczkami" ([KB] 2005, s. 7).

Oddział MHK Fabryka Schindlera nie powinien być rozpatrywany w oderwaniu od urbanistycznego kontekstu. W 2007 r. decyzją władz miasta, które dwa lata wcześniej przejęło na własność fabryczne zabudowania, fabryka została podzielona między dwie instytucje - MHK, które zajęło budynek administracyjny oraz Muzeum Sztuki Współczesnej, dla którego przeznaczono fabryczne hale. Obie instytucje sąsiadują ze sobą — główne wejście do muzeum sztuki znajduje się tuż za historyczną bramą fabryki od strony ulicy Lipowej, na lewo od wejścia do muzeum historycznego. Oba muzea mieszczą się na Zabłociu, sąsiadującym z dzielnicą Podgórze, w której podczas drugiej wojny światowej istniało żydowskie getto. Jeszcze na początku XXI wieku była to jedna z najbardziej zaniedbanych i niebezpiecznych części miasta, obecnie - podobnie jak wcześniej zlokalizowana na przeciwległym brzegu Wisły dzielnica Kazimierz poddawana stopniowej rewitalizacji. W roku 2005 otwarto odnowiony plac Bohaterów Getta (wcześniej plac Zgody), na którym znalazła się rzeźba-instalacja upamiętniająca tragedię żydowskich mieszkańców dzielnicy, złożona z 33 krzeseł-pomników oraz 37 krzeseł przeznaczonych do siedzenia, rozstawionych $\mathrm{w}$ przestrzeni placu. Autorami zagospodarowania placu wraz z pomnikiem są Piotr Lewicki i Kazimierz Łatak $^{8}$. W 2000 r. na Zabłociu otwarto nowo wybudowany kampus Krakowskiej Akademii im. Andrzeja Frycza Modrzewskiego (wtedy pod nazwą Krakowska Szkoła Wyższa). Nieopodal, tuż nad brzegiem Wisły, na terenie dawnej elektrowni miejskiej, zaplanowano Muzeum Tadeusza Kantora i siedzibę Cricoteki, natomiast wśród zabudowań fabrycznych (w XIX i XX wieku dzielnica podlegała intensywnej, często chaotycznej industrializacji) w szybkim tempie wyrastają apartamentowce. Fabryka Schindlera stała się częścią utworzonej w 2011 r. Trasy Pamięci, na którą składają się również dwa inne oddziały MHK — Apteka Pod Orłem położona przy Placu Bohaterów Getta

\footnotetext{
${ }^{8}$ Krzesła stanowią odwołanie do zapisu z książki Tadeusza Pankiewicza (1995, s. 240), właściciela „Apteki Pod Orłem”, która w latach 1941-1943 za zgodą niemieckich władz działała w getcie: „Apteka w getcie krakowskim: Na placu Zgody niszczeje nieprzeliczona ilość szaf, stołów, kredensów i innych mebli, przenoszonych nie wiadomo już po raz który z miejsca na miejsce".
} 
oraz Ulica Pomorska — oddział mieszczący się w byłej krakowskiej siedzibie gestapo, prezentujący wystawę stałą Krakowianie wobec terroru 1939-1945-1956. Założeniem trasy jest możliwie pełna prezentacja dziejów Krakowa w czasie wojny oraz w latach powojennych.

\section{POSTINDUSTRIALNY KONTEKST DLA SZTUKI WSPÓŁCZESNEJ}

Chociaż Fabryka Schindlera nie jest muzeum prezentującym technologię wyrobu produkowanych tu naczyń emaliowanych, to w części odnosi się do historii fabryki. Dopełnieniem tego muzeum jest pod względem charakteru zbiorów znajdujące się na przeciwległym biegunie Muzeum Sztuki Współczesnej w Krakowie (MOCAK). Historia muzeum artystycznego postulowanego w Krakowie co najmniej od lat dziewięćdziesiątych XX wieku zaczęła się w roku 2004, kiedy ówczesny minister kultury uruchomił ogólnopolski program wspierania sztuki współczesnej „Znaki Czasu”. Została wtedy powołana przez marszałka województwa Małopolska Fundacja Muzeum Sztuki Współczesnej, której celem - podobnie jak piętnastu innych podobnych stowarzyszeń powstałych w niemal wszystkich województwach — było zbudowanie kolekcji sztuki współczesnej, jej promocja w społeczeństwie, a w dalszej perspektywie zainicjowanie instytucji ze stałą siedzibą (w dokumentach programowych była mowa o tzw. centrach nowoczesności), która mogłaby tę kolekcję pomieścić. W tworzenie muzeum zaangażowali się w tym samym czasie marszałek Małopolski i prezydent Krakowa, i każdy z nich wystąpił z własną propozycją lokalizacji. Marszałek proponował zaadaptowanie na cel muzeum sztuki współczesnej historycznego budynku dworca kolejowego, w którego bezpośrednim sąsiedztwie budowano w tym czasie centrum handlowe, hotele oraz osiedle apartamentowców. Kwartał ten określono mianem Nowego Miasta - funkcja kulturalna miałaby stanowić uzupełnienie części rezydencjonalno-komercyjnej. Prezydent natomiast forsował pomysł zlokalizowania muzeum na terenie historycznej fabryki Schindlera, którą w tym czasie miasto przejęło na własność. W prasie (zwłaszcza na łamach „Gazety Wyborczej”) rozgorzała dyskusja nad przyszłą lokalizacją, a do dwóch koncepcji politycznych dziennikarze, przedstawiciele środowiska historyków sztuki i artystów dodawali kolejne propozycje — fabrykę Peterseimów ${ }^{9}$ czy plac Na Groblach.

Ostatecznie do utworzenia muzeum doprowadziło miasto. W czasie toczącej się w mediach debaty fabryka Schindlera była krytykowana jako miejsce

\footnotetext{
${ }^{9}$ W 2006 r. Urząd Marszałkowski rozpisał konkurs skierowany do studentów i absolwentów architektury, urbanistyki i planowania przestrzennego w województwie małopolskim na opracowanie ideowo-studialnej koncepcji architektoniczno-urbanistycznej na Centrum Sztuki Nowoczesnej w Krakowie. Można było przedstawić projekt dla jednej z dwu proponowanych lokalizacji: budynku dworca lub dawnych zakładów Peterseima. Nie przyznano głównej nagrody, jedynie wyróżniony został projekt adaptacji fabryki Peterseima. Ze względów własnościowych realizacja muzeum w tej lokalizacji okazała się niemożliwa.
} 
ewentualnej prezentacji sztuki współczesnej - wiele osób było zgodnych, że na tym terenie powinno powstać muzeum historyczne, a sztuka współczesna $z$ uwagi na swój bezkompromisowy charakter może okazać się nieodpowiednia dla miejsca pamięci ${ }^{10}$. Wolą prezydenta miasta działka została podzielona między dwie instytucje, $z$ których jedna odniosła się do przeszłości miejsca, drugą natomiast przeznaczono na laboratorium współczesności. Charakter obu instytucji jest czytelny już z perspektywy ulicy, kiedy spogląda się na ich tkankę architektoniczną. Oddział MHK powstał w wyremontowanym budynku, jedynie w prosty sposób zaadaptowanym do pełnienia funkcji wystawienniczych. W budynku nie ma form nowej architektury, dodano jedynie wyposażenie niezbędne z punktu widzenia narracji wystawy i komfortu zwiedzających. MOCAK natomiast reprezentuje dialog starej i nowej architektury. W 2007 r. przeprowadzony został konkurs architektoniczny, który zakładał adaptację sześciu istniejących budynków fabryki oraz budowę nowego gmachu służącego jako przestrzeń ekspozycyjna. Zwycięskie studio architektoniczne, Claudio Nardi Architetto $z$ Florencji, zaproponowało minimalistyczną w wyrazie formę głównego gmachu, która przez zastosowanie szedowego dachu naśladuje formę wcześniejszych zabudowań fabrycznych. Ceglane ściany fabryki zostały „wtopione” w nową bryłę stanowiącą grę metalu i szkła — jedna ze ścian jest w całości odsłonięta, widoczna na całej długości za szybą, która prowadzi zwiedzających krętą wewnętrzną uliczką z ulicy Lipowej do głównego wejścia, pozostałe zostały ukryte za nowoczesnymi materiałami. Budynek mieszczący dwie kondygnacje sal wystawowych został częściowo schowany pod powierzchnią ziemi, przez co nie dominuje w fabrycznym krajobrazie okolicy. Architekt zastosował ponadto system wysokich na kilka metrów kamiennych przegród, które oddzielają budynek od ulicy i jednocześnie wprowadzają kameralną atmosferę dziedzińca, jaki powstał między budynkiem głównym i zabudowaniami pomocniczymi MOCAK-u (przeznaczonymi na mniejsze sale wystawowe, bibliotekę, biura i pracownie konserwatorskie) a budynkiem frontowym, w którym mieści się MHK.

Realizacja MOCAK-u, podobnie jak Muzeum Powstania Warszawskiego, została wprzęgnięta w politykę i kampanię wyborczą. MOCAK został bowiem otwarty na pięć dni przed wyborami samorządowymi, w których urzędujący prezydent ubiegał się o reelekcję. Muzeum otwarto w stanie surowym, bez wyposażenia i tym bardziej bez którejkolwiek z planowanych na otwarcie wystaw, co spowodowało falę krytyki ze strony środowiska i mediów (zob. Handz-

\footnotetext{
10 Przeciwny był m.in. Andrzej Starmach, twierdzący, że „muzeum sztuki współczesnej nie może powstać w żadnym miejscu, które w jakikolwiek sposób kojarzy się z martyrologią i holokaustem. Trzeba pamiętać, że sztuka aktualna jest bardzo różna — czasem mocno publicystyczna i krytyczna wobec rzeczywistości, bywa też polityczna. Muzeum musi więc być absolutnie neutralnym ideologicznie miejscem. [...] A już pomysł połączenia sztuki współczesnej z muzeum Żegoty w jednym budynku uważam za kuriozalny" (kb 2005).
} 
lik 2010, s. 2). Sam Jacek Majchrowski otwarcie przyznał: „Skoro byłem pomysłodawcą tego muzeum, wykupiłem te tereny, wystąpiłem o środki unijne i przygotowałem konkursy, to chyba mam prawo pokazać, że to ja zrobiłem" (Hajok, Handzlik 2010, s. 3). MOCAK to jedno z trzech muzeów otwartych przez prezydenta w 2010 r. — prócz Fabryki Schindlera zwiedzającym została udostępniona również podziemna trasa zwiedzania średniowiecznego Rynku zatytułowana Śladem europejskiej tożsamości Krakowa — kolejny oddział MHK.

Wróćmy do zagadnienia miejsca - lokalizacji muzeum. Trafne argumenty za wyborem Fabryki Schindlera wysunęli w dyskusji prezes krakowskiego oddziału SARP Piotr Gajewski, który podkreślał, że na terenie fabryki nie ginęli ludzie (Hajok 2005), a także Ryszard Horowitz, fotografik w dzieciństwie więziony w Auschwitz, który zauważył, że fabryka „nie została naznaczona krwią, a wiąże się z wydarzeniami pełnymi optymizmu i wiary w człowieka" (Kursa 2007, s. 1). Wystawa zorganizowana na otwarcie muzeum, które nastąpiło wiosną 2011 r., została zatytułowana Historia w sztuce. Zaprezentowane na niej prace odnosiły się do wielu różnych momentów historycznych i reprezentowały różne sposoby ich interpretacji, jednak dominowała problematyka drugiej wojny światowej i Holokaustu.

W procesie rewitalizacji dzielnicy będzie uczestniczyć również trzecia placówka muzealna, jak dwie poprzednie adaptująca istniejącą zabudowę - Muzeum Tadeusza Kantora i siedziba Cricoteki. Powstanie na terenie nieczynnej elektrowni Podgórskiej ${ }^{11}$, której historyczna forma zostanie „opakowana” nową architekturą w kształcie przęsła mostu. Wyłoniony w 2007 r. w konkursie architektonicznym projekt został nagrodzony za „ambitną próbę zbudowania przestrzeni publicznej będącej jednocześnie sceną i widownią - miejscem nieustannego spektaklu", który z jednej strony stanowi nawiązanie do sztuki Kantora (,idea ambalażu i sztuki konfliktu, spięcia, łamania stereotypów i prowadzenia niecodziennymi zderzeniami form i treści”), a z drugiej dobrze wpasowuje się w kontekst przestrzenny położonej nad Wisłą działki. Dzielnica - wyznaczona trzema muzeami, szkołą wyższą, miejscami pamięci, a także powstającymi apartamentowcami i kawiarniami — w założeniu ma się stać nowym centrum kulturalnym miasta. Ułatwi to dobra komunikacja z centrum oraz otwarta w 2010 r. kładka dla pieszych, która połączyła Podgórze z popularnym Kazimierzem.

W Łodzi, podobnie jak w Krakowie, elementem rewitalizacji zabytkowej części miasta stało się Muzeum Sztuki. W tym przypadku do głosu doszły nie kwestie polityczne, lecz raczej wizerunkowy interes dewelopera - francuskiej spółki Apsys, która na etapie budowy centrum handlowo-rozrywkowego „Manufaktura" zdecydowała się przeznaczyć jeden z budynków na potrzeby publicz-

11 Zgodnie $z$ harmonogramem prac budynek powinien zostać oddany do użytku w $2012 \mathrm{r}$. (arch. IQ2 Konsorcjum Wizja Sp. z o.o. - Stanisław Deńko oraz nsMoonStudio Sp. z o.o. — Piotr Nawara, Agnieszka Szultk). 
nego muzeum. Kompleks powstał na terenie historycznej fabryki Towarzystwa Akcyjnego Wyrobów Bawełnianych I. K. Poznańskiego. Budynki z czerwonej cegły zaczęto wznosić w 1872 r., a kolejne powstawały aż do lat siedemdziesiątych XX wieku. W okresie największej prosperity, w latach dziewięćdziesiątych XIX wieku, fabryka zajmowała teren o powierzchni $270000 \mathrm{~m}^{2}$. W $1999 \mathrm{r}$. zabudowania zostały zakupione przez francuskiego inwestora i w latach 2003-2006 w ich obrębie powstało nowe centrum Łodzi, stanowiące alternatywę dla ciągnącej się przez kilka kilometrów ulicy Piotrkowskiej.

Łódzkie muzeum od momentu powstania borykało się z problemami lokalowymi. Siedziba w Pałacu Poznańskich nie była w stanie sprostać wymogom kolekcji sztuki współczesnej, a jej rozmiary powodowały, że historyczna Międzynarodowa Kolekcja Sztuki Nowoczesnej oraz zbiory sztuki współczesnej były prezentowane $\mathrm{w}$ formie wystaw zmiennych. W 1973 r. muzeum otrzymało od miasta zespół pałacowo-ogrodowy Herbsta, co w istotny sposób powiększyło jego przestrzeń ekspozycyjną. W tym samym roku przeprowadzono konkurs na projekt koncepcyjny nowoczesnego gmachu w Parku Kultury i Wypoczynku na Zdrowiu, w którym pierwszą nagrodę przyznano projektowi Jana Fiszera, inwestycja nie doszła jednak do skutku z powodu cięć finansowych. W $1980 \mathrm{r}$. powstał Społeczny Komitet Budowy Gmachu Muzeum Sztuki w Łodzi. Szansa na nowy budynek pojawiła się w 2004 r. - wtedy właśnie inwestor „Manufaktury" zdecydował się przekazać muzeum budynek tkalni wysokiej. Można się zastanawiać nad motywami tej decyzji. Przekonujące wydaje się domniemanie dziennikarza lokalnego wydania "Gazety Wyborczej”, który stwierdził: „Tradycyjne centra handlowe nie mają już przyszłości. Na otwarcie kolejnych supermarketów przychodzi coraz mniej ludzi, wszystkie są przecież do siebie bliźniaczo podobne. Francuski inwestor, który ściąga kulturę do Manufaktury, nie robi tego z czystej filantropii. Szuka sposobu na przyciągnięcie klientów i znalazł doskonały" (Michałowicz 2004). Budynek na terenie „Manufaktury” to ratunek dla muzeum, ale również bezprecedensowe w skali Polski wyzwanie, by zmierzyć się z komercyjnym sąsiedztwem. Podczas prac adaptacyjnych i tuż po otwarciu nowej siedziby pojawiało się wiele pytań (zwłaszcza na łamach prasy codziennej), czy usytuowanie muzeum nie wpłynie na obniżenie i „uludycznienie” ambitnego programu. Dyrekcja wielokrotnie ustosunkowywała się do zarzutów nieuchronnej popularyzacji i komercjalizacji. „Niektórym umiejscowienie muzeum w sąsiedztwie komercyjnego centrum może wydawać się kontrowersyjne. Moim zdaniem, jest to jednak szansa na zniesienie sztucznych granic dzielących tak zwaną "kulturę wysoką" od tego, czym człowiek żyje na co dzień - wyjaśniał dyrektor Muzeum Sztuki Jarosław Suchan. Granic, które wielu onieśmielają, sprawiając, że muzea sztuki są przez nich omijane szerokim łukiem. Dlatego $\mathrm{w}$ programie $\mathrm{ms}^{2}$ przewidujemy różne projekty, które będą starały się pokazywać, że sztuka nowoczesna jest istotną częścią naszego życia, a nie wyrafinowanym hobby garstki estetów" (Kowalewicz 2008, s. 2). 
Dowodem na nieuleganie popularnym gustom jest realizowany od $2008 \mathrm{r}$. na terenie „Manufaktury” program wystaw i wydarzeń towarzyszących. Muzeum jednak, chociażby poprzez środki zastosowane w układzie przestrzennym oraz zabiegi artystyczne, działa jako przestrzeń otwarta. Służy temu formuła wejścia do muzeum. Wejście główne zlokalizowane jest od strony dziedzińca „Manufaktury”, czyli w elewacji, która niemal na całej długości jest „doklejona" do reprezentującego nową architekturę centrum handlowego. Wyznacza je rzeźba Jarosława Kozakiewicza Drzwi do muzeum - kilkumetrowa forma ze stali powtarzająca kształt ślepej arkady, której głównym celem jest wyróżnienie wejścia na tle powierzchni sklepowych i usługowych. Sam artysta przyznał: „Nie mogłem ingerować ani w budynek, ani w posadzkę, chociaż oczywiście najwłaściwsze byłoby działanie architektonicznie wyraźniej zaznaczające wejście do muzeum, powiększające drzwi. Mój obiekt będzie zmieniał kolor. Te drzwi są z stali kortenowskiej, która reaguje na wilgoć. Praca będzie rdzewiała, pojawią się przebarwienia. To też może być intrygujące dla osób odwiedzających" (MS2 2008). Drugie wejście usytuowane jest po przeciwnej stronie gmachu, w całości widocznej ceglanej elewacji, przy której znajduje się parking, a za nim ciągnie się ulica wyznaczająca granicę kompleksu. $Z$ poziomu parkingu do muzeum - bezpośrednio na pierwsze piętro - prowadzi metalowo-szklana rampa. Nie jest to droga do kasy (ta znajduje się na parterze) ani bezpośrednio do sali wystawowej, lecz do muzealnej kawiarni. Ten prosty zabieg z buforową przestrzenią wejścia „oswaja” zwiedzającego z przestrzenią „świątyni sztuki”.

Pod względem struktury architektonicznej elewacje budynku pozostały niezmienione - czerwona cegła i rzędy łukowo zamkniętych okien (stolarka okienna została wymieniona) są elementem charakterystycznym całej historycznej zabudowy „Manufaktury”. Wnętrze muzeum wypełnia biel ścian, nie jest to jednak ortodoksyjny white-cube. Ceglany strop odcinkowy, a także ceglane wątki muru są widoczne w przestrzeniach wejścia - hole, księgarnia, kawiarnia, klatki schodowe, w białych salach wystawowych ceglana czerwień przebija się również w ścianie przeprutej oknami. Poszczególne kondygnacje wypełniają rzędy filarów, które tworzą swojego rodzaju nawy. Tożsamość miejsca została w budynku zachowana, chociaż nie przepracowano jej — jak później w Krakowie - w programie wystawienniczym muzeum.

MOCAK i $\mathrm{ms}^{2}$ to $\mathrm{w}$ Polsce jedyne muzea sztuki, których siedziby wykorzystujące budynki postindustrialne zostały oddane do użytku w pierwszej dekadzie XXI wieku. Kilka kolejnych siedzib innych instytucji zostało w tym okresie zaprojektowanych. Jedną z największych jest nowe Muzeum Śląskie w Katowicach, na którego lokalizację wybrano teren nieczynnej Kopalni Węgla Kamiennego „Katowice” ${ }^{12}$. W konkursie architektonicznym w 2007 r. zwycię-

12 Muzeum Śląskie powstało w 1929 r. W tym samym roku ogłoszony został pierwszy konkurs architektoniczny na projekt nowego gmachu, do realizacji nie wybrano jednak żadnego projektu. 
żyła austriacka pracownia Riegler Riewie Architecten. Projekt zakłada rewitalizację pokopalnianego terenu zlokalizowanego w centrum Katowic, w bezpośrednim sąsiedztwie hali widowiskowej „Spodek”. Nowy budynek pełniący funkcje ekspozycyjne znajdzie się pod powierzchnią ziemi, a jego obecność sygnalizować będą szklane wieże doświetlające podziemne sale wystawowe. Ma to być nawiązanie do górniczej tradycji Śląska - rolę podziemnego skarbu, jakim był węgiel, przejmą dzieła sztuki. Tylko jeden nowy budynek, przeznaczony do pełnienia funkcji konferencyjno-biurowych, będzie gmachem nadziemnym. Na cele muzealne zostaną zaadaptowane także historyczne zabudowania kopalniane: dawna maszynownia szybu „Warszawa” na restaurację, $\mathrm{w}$ dawnym magazynie odzieżowym znajdzie się Centrum Scenografii Polskiej, a dawna wieża wyciągowa szybu „Warszawa” zostanie przekształcona w wieżę widokową. Przez charakter zgromadzonej kolekcji muzeum będzie związane $\mathrm{z}$ miejscem. Prezentowane $\mathrm{w}$ nim będzie zarówno polskie malarstwo, jak i zajmująca niemal taką samą powierzchnię wystawienniczą historia Śląska. Kompleks muzealny stanie się częścią tzw. osi kultury, która obejmie Międzynarodowe Centrum Kongresowe usytuowane tuż przy „Spodku” oraz siedzibę Narodowej Orkiestry Symfonicznej Polskiego Radia w Katowicach.

Na początku XXI wieku w budynkach postindustrialnych powstało także wiele instytucji niemuzealnych - centrów sztuki i galerii. W 2004 r. na terenie centrum handlowo-rozrywkowego „Stary Browar” w Poznaniu zaczęła działać Galeria Art Stations. Sama galeria reprezentuje nową architekturę, należy jednak do kompleksu powstałego na terenie historycznego browaru, którego część została zachowana, a część nowa nawiązuje architektoniczny dialog z przeszłością miejsca. Rok wcześniej w Łodzi budynek dawnej hali targowej stojący na rozległym podwórzu przy ulicy Piotrkowskiej został zaadaptowany na galerię Atlas Sztuki. Z kolei w 2001 r. w Katowicach, na terenie hali Kopalni Wieczorek, zaczęła działać Galeria Szyb Wilson. Na realizację czekają również Mazowieckie Centrum Sztuki Współczesnej „Elektrownia” w Radomiu, w zaadaptowanym budynku elektrowni miejskiej, druga siedziba Galerii Arsenał w Białymstoku na terenie starej elektrowni oraz Trafostacja Sztuki w Szczecinie - centrum sztuki współczesnej w budynku historycznej transformatorowi.

W 1936 r. wojewoda śląski zlecił wykonanie projektu muzeum Karolowi Schayerowi. Budowa gmachu zakończyła się w 1939 r., jednak przed wybuchem wojny muzeum nie zdążyło się do niego wprowadzić. Hitlerowcy nakazali jego rozbiórkę. Przeprowadzono ją w latach 1941-1944, a samo muzeum zostało zlikwidowane. Budynek hotelu, do którego wprowadziło się po wojnie reaktywowane muzeum, był przewidziany jako siedziba tymczasowa. W 1986 r. ogłoszono wyniki konkursu architektonicznego na nowy gmach, który miał stanąć przy ulicy Ceglanej. Autorem projektu był Jan Fischer. Prace projektowe trwały do 1990 r. Nie rozpoczęto budowy, gdyż środki zostały skierowane na budowę Biblioteki Śląskiej. 


\section{MODA CZY COŚ WIĘCEJ?}

Instytucji muzealnych i wystawienniczych adaptujących na potrzeby swoich siedzib istniejące zabudowania jest obecnie bardzo dużo. Ponieważ placówek o muzealnym przeznaczeniu $\mathrm{w}$ drugiej połowie XX wieku powstało $\mathrm{w}$ Polsce bardzo niewiele, postindustrialne i historyczne budynki stały się ratunkiem dla zbiorów stłoczonych $\mathrm{w}$ magazynach $\mathrm{z}$ powodu niedostatecznej powierzchni ekspozycyjnej. Przystosowanie budynku jest bowiem zazwyczaj tańsze od budowy nowego gmachu (chociaż oczywiście koszt zależy od tego, czy następuje prosta, ascetyczna adaptacja budynku do pełnienia funkcji muzealnych czy wystawienniczych, czyli remont, czy też istniejące elementy zabudowy zostają wpisane w nową architekturę). Koszt to jedna z przyczyn. Kolejną jest miejsce - w miastach liczba atrakcyjnych działek niezabudowanych lub z zabudową kwalifikującą się do wyburzenia nie jest duża, a adaptacja historycznego obiektu (często wpisanego przy tym na listę zabytków) bywa szansą na pozyskanie dogodnej lokalizacji. Przyczyną może być również charakter budynku — produkcyjna tożsamość dobrze współgra ze sztuką współczesną. Budynki postindustrialne oznaczają powrót do korzeni, gdyż w takich właśnie przestrzeniach często sztuka współczesna powstaje. Wszystkie te elementy, a zwłaszcza ostatni, składają się na muzealną modę. Przytoczone tu przykłady potwierdzają przekonanie, że adaptacja istniejących obiektów na muzea i inne instytucje wystawiennicze przyjęła charakter masowej mody zaczerpniętej z krajów Zachodu.

Pozostaje więc postawione we wstępie pytanie: Czy muzea muszą podążać za modą? Odpowiedź jest trywialna - modne muzeum oznacza sukces frekwencyjny, a z kolei sukces frekwencyjny to sukces na wszystkich innych polach. Okazuje się jednak, że frekwencja to nie wszystko, że ten sukces może stać się również przekleństwem. Na przykład Tate Modern, do którego pod względem typu zabudowań nawiązują Muzeum Powstania Warszawskiego oraz przyszłe Muzeum Tadeusza Kantora, Mazowieckie CSW „Elektrownia” i druga siedziba Galerii Arsenał, było projektowane na przyjęcie dwóch milionów zwiedzających rocznie, przyciąga jednak każdego roku od czterech do pięciu milionów osób. $Z$ tego względu konieczne okazało się powiększenie powierzchni ekspozycyjnej. W 2006 r. władze muzeum ogłosiły projekt rozbudowy gmachu o nowe skrzydło, które da dodatkowe $7000 \mathrm{~m}^{2}$ powierzchni wystawienniczej (do istniejących $9000 \mathrm{~m}^{2}$, nie licząc ogromnego Holu Turbin). Ma on zostać otwarty na Igrzyska Olimpijskie w Londynie w roku 2012. Inaczej na rosnącą liczbę zwiedzających zareagowała Sammlung Goetz w Monachium. To prywatna kolekcja sztuki od 1992 r. prezentowana w nowym, minimalistycznym budynku, oddalonym od centrum miasta, zlokalizowanym w spokojnej, wypełnionej zielenią dzielnicy rezydencjonalnej, ukrytym za wysokim ogrodzeniem. O jej istnieniu nie informuje żadna tabliczka czy nazwa umieszczona na fasadzie. Gdy okazało się, że liczba zwiedzających przekracza możliwości 
zapewnienia komfortu zwiedzania i bezpieczeństwa zbiorom, wprowadzono konieczność umawiania się na wizytę ${ }^{13}$.

W przypadku Tate Modern wydaje się, że siłą przyciągającą zwiedzających jest nie tylko sztuka - kolekcja i wystawy czasowe - lecz również fakt, że budynek został wykreowany na światową ikonę współczesności. Wielka, katedralna przestrzeń $z$ „wypatroszoną" maszynerią, ciągi ruchomych schodów fantazyjnie łączących kilka kondygnacji, przestrzenie wypoczynku z widokiem na wejściową rampę, ogromna, rozświetlona księgarnia, kawiarnia z tarasem widokowym na Tamizę i restauracja $z$ wielkim oknem zapewniającym spektakularny widok na panoramę miasta — to również istotne powody wizyty w muzeum, która wcale nie musi się kończyć przeżyciem estetycznym w sali wystawowej. Czy muzea w Polsce są skazane na dążenie do sukcesu frekwencyjnego? Muzeum Powstania Warszawskiego pod wieloma względami podąża za wzorem Londynu, natomiast turystycznie świetna lokalizacja $\mathrm{ms}^{2}$ nie przekłada się już $\mathrm{w}$ takim stopniu na liczbę zwiedzających. W tym przypadku tematyka wydaje się kluczowa - wychowanie patriotyczne ma w Polsce o wiele wyższą rangę niż wychowanie artystyczne. Nie ulega wątpliwości, że inwestorzy, decydenci i twórcy instytucji chcą wpisywać swoje projekty w światowe trendy. Adaptacja istniejących budynków jest tym bardziej atrakcyjna, że wymaga niższych nakładów niż kompletnie nowe inwestycje, a jednocześnie może stać się elementem rewitalizacji całych dzielnic. Tworzenie „modnych” instytucji w niektórych przypadkach zaczyna jednak przybierać nieco karykaturalne kształty. Można tu wskazać chociażby produkcję gadżetów. Iga Nyc poruszyła ten problem na przykładzie Muzeum Powstania Warszawskiego: „Puszka landrynek ze zdjęciami zniszczonej Warszawy, podkładki pod mysz komputerową z powstańczą kotwicą, kolorowanka z łączniczką na okładce i temperówka-bombowiec. Marketing obowiązuje dziś w każdej branży, nawet historię trzeba ładnie opakować, aby ją sprzedać. Dlatego na Allegro.pl można kupić T-shirty z wizerunkami żołnierzy AK. Zysk idzie na produkcję zniczy i wieńców, które 1 sierpnia zostaną złożone $\mathrm{w}$ miejscach pamięci. Legenda powstania przesunęła się w stronę popkultury" (Nyc 2010, s. 89). Na większą wolność pod tym względem może sobie pozwolić muzeum sztuki. Księgarnia MOCAK-u ma $\mathrm{w}$ ofercie prace artystów i projektantów, w tym na przykład Męskie ramię, Lale $z$ tata ${ }^{14}$ i Poduchy-Cipuchy autorstwa Iwony Demko oraz Poduszki Cy-

13 Autorem wszystkich trzech budynków - adaptacji elektrowni, nowej dobudówki i siedziby kolekcji Goetz jest szwajcarska pracownia architektoniczna Herzog \& de Meuron.

14 Autorski opis artystki dostępny na stronie internetowej muzeum: „Męskie ramię: Produkt przeznaczony dla Singielek i Singli. Zapewnia spokojny, niczym niezmącony sen. Doskonale nadaje się na samotne noce, wspaniale zaspokaja nieoczekiwane tęsknoty. Nie chrapie, nie sapie, nie ma humorów, nie obraża się. A co najważniejsze, NIE DRĘTWIEJE i nie budzi nad ranem...”; „Lala z łałą: Wszystkie lalki dla dziewczynek nie mają bardzo ważnej części ciała - jest ona zwykle zupełnie pomijana, właściwie nie wiadomo dlaczego. Kiedy byłam mała, mówiłam na nią: łała" (MOCAK Bookstore). 
cuszki sygnowane Grupa Kuku Kuku, Katarzyna Kukuła. Nad ich wartością artystyczną można się zastanawiać, podobnie jak dyskusyjny jest tzw. dobry smak.

Modę, która może zawieść donikąd, świetnie skomentował Mirosław Bałka w instalacji-obiekcie Auschwitzwieliczka, która w 2009 r. stanęła w Krakowie. Neologizm nawiązuje do turystycznych ofert zwiedzania Krakowa, których obowiązkowym punktem jest wizyta w obozie koncentracyjnym Auschwitz-Birkenau i w Kopalni Soli „Wieliczka” - istnieje możliwość zwiedzenia obu znacznie oddalonych od siebie „atrakcji” w ciągu zaledwie kilku godzin. Rzeźba ma kształt korytarza z wyrytym w suficie napisem Auschwitzwieliczka, który w słoneczny dzień pojawia się na wewnętrznej ścianie dzięki grze światła i cienia. Przez korytarz można swobodnie przejść, co ma obrazować ekspresowe przemieszczanie się grup turystycznych z obozu koncentracyjnego do kopalni oraz powierzchowność doznań, które symbolizuje prosta, szara ściana korytarza. Rzeźba stanowi przenośnię błyskawicznego, bezrefleksyjnego zwiedzania, w którym liczy się liczba widzianych obiektów, a nie wyniesione $z$ nich doświadczenie. Można ją odnieść również do muzealnego zwiedzania w ogóle, do podążania za modą. Zwłaszcza że Auschwitzwieliczka ustawiana jest obecnie na trakcie komunikacyjnym między przystankiem tramwajowym a Fabryką Schindlera i MOCAK-iem ${ }^{15}$.

Wydaje się, że mimo zagrożeń muzea za modą podążać będą - modą rozumianą na wielu poziomach i polach: lokalizacji, tożsamości miejsca, tematu i sposobu jego prezentacji, komercyjnej obudowy — a sukces frekwencyjny jest tym, do czego należy dążyć — zwłaszcza w kraju, w którym modę na chodzenie do muzeów dopiero się kreuje ${ }^{16}$. Instytucje muzealne, zwłaszcza muzea sztuki, działające w obiektach postindustrialnych, w zaniedbanych dzielnicach, często kreują się na miejsca alternatywne. Jest ich jednak coraz więcej, co sprawia, że ta alternatywność stała się już częścią głównego nurtu kultury. Muzealna moda nie jest niczym złym, nawet jeśli oznacza powielanie pomysłów i wzorów, bo dzięki niej powstają nowe instytucje, a społeczeństwo coraz chętniej je odwiedza. Ważne jest tylko, aby bycie „modnym” nie zdominowało powodu, dla którego przychodzi się do muzeum - czyli po wiedzę, po przeżycia estetyczne i intelektualne.

15 Rzeźba stanęła pierwotnie na Rynku Podgórskim, gdzie stała się przedmiotem krytyki i wandalizmu, w związku z czym została przetransportowana w inne miejsce. Powodem braku akceptacji społecznej było niepowiązanie z kontekstem miejsca. „Historia korytarza Bałki przynosi naukę, jak ostrożnie trzeba postępować ze sztuką w przestrzeni publicznej. Nie wystarczy zamówić rzeźbę i umieścić ją tam, gdzie jest wolne miejsce. Miasto widziało w pracy Bałki potencjał marketingowy, nie uszanowało jednak prawdziwych dysponentów i użytkowników przestrzeni miejskiej" (Ujma 2009).

16 Tłumy każdego roku uczestniczące w Nocy Muzeów są dowodem na to, że modę na muzea da się marketingowymi sposobami wykreować. 


\section{BIBLIOGRAFIA}

Bednarek Monika, 2010, Kraków - czas okupacji 1939-1945. Zarys koncepcji wystawy, w: Monika Bednarek i in., Kraków - czas okupacji 1939-1945, Muzeum Historyczne Miasta Krakowa, Kraków.

Cantacuzino Sherban, 1975, New Uses for Old Buildings, Whitney Library of Design, New York.

Cantacuzino Sherban, 1989, Re-architecture: Old Buildings / New Uses, Abbeville Press, New York.

Chwalba Andrzej, 2010, Wprowadzenie, w: Monika Bednarek i in., Kraków — czas okupacji 1939-1945, Muzeum Historyczne Miasta Krakowa, Kraków.

Cossons Neil, 2008, Yesterday's Industry, Tomorrow's Legacy?, w: Benjamin Fragner (red.), Průmyslové dĕdictví / Industrial heritage, VCPD, Praha.

Folga-Januszewska Dorota, 2009, Muzea w Polsce 1989-2009, „Muzealnictwo”, nr 50.

Hajok Dawid, 2005, Niepewne losy Muzeum Sztuki Wspótczesnej?, „Gazeta Wyborcza”, Kraków, 3 marca.

Hajok Dawid, Handzlik Tomasz, 2010, Stare i nowe muzeum, „Gazeta Wyborcza”, Kraków, 17 listopada.

Handzlik Tomasz, 2010, Prezydent gra pustymi murami MSW, „Gazeta Wyborcza”, Kraków 16 listopada.

Jagodzińska Katarzyna, 2009, Od muzeum Schindlera do wystawy o okupacji, „Art\&Business", nr 9.

[KB], 2005, Urok zamkniętego zautka — prezydent Majchrowski preferuje Fabrykę Schindlera, „Gazeta Wyborcza”, Kraków, 14 stycznia.

$\mathrm{kb}$ [K. Bik], 2005, Muzeum sztuki nowoczesnej: ani na dworcu, ani w fabryce, „Gazeta Wyborcza”, Kraków — gazeta.pl, 3 marca (http://miasta.gazeta.pl/krakow/1,35797, 2584524.html [ 20.06.2006]).

Kiciński Andrzej, 2004, Muzeum Powstania Warszawskiego w świetle konkursu architektonicznego, „Muzealnictwo”, nr 45.

Kowal Paweł, 2010, Jak budowaliśmy Muzeum, w: Przewodnik po Muzeum Powstania Warszawskiego, Lena Dąbkowska-Cichocka i in. (red.), Muzeum Powstania Warszawskiego, Warszawa.

Kowalewicz Krzysztof, 2008, $\mathrm{ms}^{2}$ czyli sztuka spotegowana, rozmowa z Jarosławem Suchanem, „Muzeum Sztuki”, dodatek do „Gazety Wyborczej”, Łódź, 14 listopada.

Kursa Magdalena, 2007, Niepokój Horowitza, „Gazeta Wyborcza”, Kraków, 5 lipca.

Michałowicz Tomasz, 2004, Muzeum Sztuki z przyszłościa, „Gazeta Wyborcza”, 19 stycznia.

MOCAK Bookstore, http://www.mocak.com.pl/aktualnosci/pokaz/57 [29.06.2011].

MS2 - Nowa przestrzeń sztuki, „Bryła”, 24 listopada 2008, http://bryla.gazetadom.pl/ bryla/1,85301,5982834,MS2 Nowa_przestrzen_sztuki.html [30.06.2011].

Niezabitowski Michał, 2010, Stowo wstępne, w: Monika Bednarek i in., Kraków - czas okupacji 1939-1945, Muzeum Historyczne Miasta Krakowa, Kraków.

Nyc Iga, 2010, Powstanie przy grillu, „Wprost”, nr 31.

Pankiewicz Tadeusz, 1995, Apteka w getcie krakowskim, Wydawnictwo Literackie, Kraków. Projekt, http://cricotekawbudowie.pl/pl,inagroda [27.06.2011].

Stratton Michael (red.), 2000, Industrial Buildings: Conservation and Regeneration, Spon, London. 
Szostkiewicz Adam, 2010, Zabawy historia, „Polityka”, 4 września.

Ujma Magdalena, 2009, „Auschwitzwieliczka” Mirosława Batki: kontrowersje wokót sztuki w przestrzeni publicznej, „Kwartalnik Rzeźby OROŃSKO”, nr 5-6.

Wiśniewska Maria, 2004, Muzeum Powstania Warszawskiego otwarte!, „Muzealnictwo”, nr 45.

[wot], 2007, Wybierz nowe ikony Warszawy, „Gazeta Wyborcza.pl”, 16 lutego http:// wyborcza.pl/1,75248,3926023.html [24.06.2011].

\section{HISTORICAL CONSTRUCTIONS FOR NEW MUSEUMS: MUSEUM TRENDS AT THE BEGINNING OF $21^{\text {ST }}$ CENTURY}

\section{Sum mary}

The Author considers a trend, which comes from the west, to use post-industrial developments for museums. The article includes issues concerning adaptation of post-industrial developments for museum functions, references to history and identity of the building concerned, as well as relations of an institution - which is hosted within the historical construction - with the surroundings. The museums which have been selected for the analysis are representative for a boom observed in Poland since the beginning of the $21^{\text {st }}$ century - the majority of newly-established museums are located in adapted old buildings, the museums representing almost exclusively only two categories: historical museums and contemporary art museums. The Author seeks an answer to a question whether museums must follow current trends. She concludes that a quest for success translating to a good image and high attendance is and certainly shall remain an important goal of a museum. She warns, however, of dangers related with a museum trying to be a "trendy" place to attend, especially in the times of public life commercialization, which is more and more common.

\section{Key words/słowa kluczowe}

historical museums / muzea historyczne; museums of contemporary art / muzea sztuki współczesnej; postindustrial architecture / architektura postindustrialna 